November 2013

\title{
Genocide, and its Definition as the "Partial Elimination of a National Group"
}

Marcelo Ferreira

School of Philosophy and Literature, and School of Law, University of Buenos Aires, Argentina

Follow this and additional works at: https://digitalcommons.usf.edu/gsp

\section{Recommended Citation}

Ferreira, Marcelo (2013) "Genocide, and its Definition as the "Partial Elimination of a National Group"," Genocide Studies and Prevention: An International Journal: Vol. 8: Iss. 1: Article 5.

DOI: http://dx.doi.org/10.5038/1911-9933.8.1.3

Available at: https://digitalcommons.usf.edu/gsp/vol8/iss1/5

This Articles is brought to you for free and open access by the Open Access Journals at Digital Commons @ University of South Florida. It has been accepted for inclusion in Genocide Studies and Prevention: An International Journal by an authorized editor of Digital Commons @ University of South Florida. For more information, please contact digitalcommons@usf.edu. 


\title{
Genocide, and its Definition as the "Partial Elimination of a National Group"
}

\author{
Marcelo Ferreira \\ School of Philosophy and Literature, and School of Law, University of Buenos Aires, Argentina
}

\begin{abstract}
Summary: This paper is primarily about the crimes committed by Argentina's last military dictatorship and whether these deserve the legal qualification of crimes against humanity or "genocide." This question has consequences which go beyond the field of law and affect society and collective psychology through the reconstruction of historical memory. From this perspective, this paper argues that the definition of Genocide set forth in international law is directly applicable in Argentine national law. It also examines the different problems with the use of this term. Finally, it aims to reconstruct the figure of Genocide from the original interpretation of the works of Raphael Lemkin, and establish the "national" group as the superordinate term and 'ethnic', 'racial' and 'religious' groups as cohyponyms, where "national" group includes and goes beyond the other three groups, and authorizes the inclusion of groups not explicitly covered by the 1948 Convention.
\end{abstract}

Keywords: Genocide, crimes against humanity, Argentina, memory, trials

Date of peer-review approval: May 30, 2012

\section{Introduction}

On March 24, 1976 the military seized power in Argentina. The de facto government headed by General Jorge Rafael Videla kidnapped, tortured and killed thousands of people. Under the pretext of a war against guerrillas, the military started a war against Argentine society as a whole. "As many as necessary will die to restore peace in Argentina," Videla promised in 1976. The following year, the former de facto governor of Buenos Aires Province, Ibérico Saint Jean, stated: "First we will kill all the subversives, then we will kill their collaborators, then their sympathizers, then those who remain indifferent, and finally we will kill the timid." To this end, over six hundred concentration camps were set up (here called 'secret detention centers'), and the term 'disappeared' became widespread. As Videla put it, a disappeared person was "an unknown entity ... They do not exist. They aren't there, either dead or alive. The person is 'disappeared"' From naval aircraft, thousands of people were thrown alive into the sea.

In order to discipline society and change the economic structure of a country which had achieved remarkable social equality and had a large middle class, the military performed a cleansing operation: a surgical action to remove the harmful elements, whose way of thinking did not fit the 'model'. Significantly, the dictatorship called itself the 'National Reorganization Process': the word 'process' means "to change from one state of affairs to another". Most victims were detained in their homes or workplaces, in the presence of witnesses, even though they were later reported to have been killed in combat. Impunity was guaranteed by the absolute silence imposed on the press and the creation of 'liberated areas' in which the military could kidnap and kill without interference from the police authorities, who were warned of operations in advance.

One of the defining features of repression was the indefinite status of the victims, whom the repressors referred to as 'subversives'. Although subversion was defined as 'Marxist', repression extended to sectors of the population that had no connection with Marxism. The qualities attributed to subversives were as diverse as: atheist, stateless, Freudian, pro-abortion, enemy of the family institution and, in general, anyone lacking in national spirit (an enigmatic trait potentially applicable to anyone).

While acting like Nazis and treating Jews with special cruelty, the military regime had a quite different ideology from National Socialism. It aimed to promote Liberalism, in the sense of a free market economy. Argentina belonged to the 'Western and Christian world'. Republican institutions were turned into caricatures of themselves; there was no longer one president but a junta, comprising the heads of the Army, Navy and Air Force. No Parliament, but parodying the notion of a balance of powers. These leaders held office for limited periods of time (there were three military juntas).

The dictatorship permeated all social institutions, not just those related strictly to politics. They clandestinely infiltrated factories and trade unions, and in schools, plain clothes police spied on school children and teachers. The tragedy led to 30,000 disappearances and 4,400 people dropped into the sea, with a network of over 600 clandestine detention centers. 


\section{Difficulties in prosecuting crimes committed during the dictatorship}

The prosecution of crimes committed in Argentina during the last military dictatorship is unprecedented worldwide. The International Federation of Human Rights has stated that Argentina is the jurisdiction for prosecuting crimes against humanity, and the UN Human Rights Council, consisting of forty-seven States, has recognized Argentina as the undisputed world leader in this area. However, although these trials do credit to Argentina's justice system, they face many obstacles that prevent them following their proper course.

Indeed, the proliferation of trials on a case-by-case basis requires an endless parade of defendants and witnesses, all of whom have to recount their sufferings time and again. Hundreds of lawsuits are filed against one, two or three individuals - each starting again from scratch in an endless replay of the same scenario. The Code of Criminal Procedure allows causes related to a particular detention center to be joined in a single trial and witness statements to be read in court, but not all courts are willing to use these provisions.

In practice, each time victims take the witness stand, they are revictimized by being forced to relive their trauma. The witnesses are in danger, and the defendants do not hesitate to threaten them. ${ }^{1}$ The Argentine judiciary does not always have available locations for the hearings. In Comodoro Py, the "Vesuvius" trial shared the same courtroom with those of the "Esma" and "ABO" (Atlético-Banco-Olimpo); while in La Plata, the Unit 9 trial has been delayed in order to refurbish La Plata's AMIA building, rented specially for the hearings.

Notwithstanding all of this, it is our contention that the main obstacle to justice in its broadest sense does not lie in substantive or procedural difficulties, but in the legal qualification of the facts. The courts classify or subsume the facts under different legal concepts - as described below - and these inevitably have long-term consequences - legal and otherwise - that will define another important value: the construction of collective memory. It is not only a question of applying penalties and sentencing the perpetrators to long years in prison (an elusive goal, given their ages), but of rescuing and uplifting the very thing the genocidaires tried to erase: our historical memory.

\section{Legal descriptions: crimes against humanity and genocide}

The Argentine Supreme Court of Justice, in "Simón, Julio Héctor et al, s / illegal deprivation of liberty, etc.," Case 17,768, placed crimes committed during the military dictatorship under the category of crimes against humanity, thereby making the defenses of prescription and amnesty inadmissible. It is an undisputed fact, then, that the crimes committed during the "National Reorganization Process" constitute crimes against humanity.

The upcoming debate, which poses a dilemma for the courts, is whether these facts can also be framed in the category of genocide. The confusion over the definition and scope of these two terms warrants closer examination. crimes against humanity means any of the acts listed in Article 7 of the Statute of the International Criminal Court, when committed in a widespread or systematic manner against a civilian population. The background of this definition is Article 6 of the Statute of the Nuremberg Tribunal, Control Council Law No. 10, resolutions 3 (I) and 95 (I) of the General Assembly of the United Nations, and the legal principles contained in those documents (codified by the International Law Commission (ILC) in 1950 as the "Nuremberg Principles").

Crimes against humanity were embodied in the Charter of the International Military Tribunal at Nuremberg in the London Agreement of August 8, 1945, and arose as a result of the failure of international military law to proscribe the Nazis crimes. The category of war crimes refers to victims who are enemy combatants and the civilian populations of occupied countries, so it could not be used to judge atrocities committed by the Nazis in Germany itself against German people: their own population. The categorycrimes against humanity was created to remedy this deficiency. ${ }^{2}$

Article 6(c) of the London Charter of the International Military Tribunal defined crimes against humanity as "murder, extermination, enslavement, deportation, and other inhumane acts committed against any civilian population, before or during the war; or persecutions on political, racial or religious grounds in execution of or in connection with any crime within the jurisdiction of the Tribunal, whether or not in violation of the domestic law of the country where perpetrated".

The broad formula contained in Article 7 of the Statute of the International Criminal Court added further categories under the following subsections: e) Imprisonment or other severe deprivation of physical liberty in violation of fundamental rules of international law, f) Torture, g) Rape, sexual slavery, forced prostitution, forced pregnancy, enforced sterilization and other serious sexual abuse; i) Enforced disappearance of persons; j) The crime of apartheid. 
Crimes against humanity draws on various historical sources, including the older notion of crimes against the law of nations, but it was the Nuremberg process that gradually gave rise to a class of crimes applicable to all States, against any person and at all times and places, even without or against the will of individual States. In contrast, offenses against the law of nations included behaviors such as piracy or the slave trade but lacked the scope currently attributed to crimes against humanity.

Crimes against humanity differ from offenses against the law of nations in their fields of validity. ${ }^{3}$ In turn, each of their fields of validity has certain characteristic features:

- Material scope: non-derogability / inadmissibility.

- Personal scope: individual responsibility / exclusion of the inadmissibility of the defenses of superior orders and official capacity.

- Timescale: non-applicability of statutory limitations / retroactive application.

- Territorial scope: universal jurisdiction.

In this sense, crimes against humanity are more than just a set of offenses grouped under the same name and designate something additional.

Crimes against humanity is a nomen iuris for a set of conditions under which the rules of domestic law can be replaced by those of international law (e.g. suspending the rule of the non-retroactive nature of criminal law). The reasoning is as follows:

- under certain circumstances (the catalog of crimes in question),

- and certain conditions (widespread or systematic attack against a civilian population),

- domestic law rules are displaced by international legal norms relating to due process of law.

The crime of torture, for example, is a crime against humanity if it occurs in the context of a widespread or systematic attack against a civilian population and is committed by people who participate in that attack. Yet this is not the case where torture is committed either in the context of an unconfirmed attack or by someone not related to the attack. It is a crime without statutory limits in the first case, but not in the second. In this sense, crime against humanity does not only refer to specific crimes; it is a qualification, which, when added to one of these crimes, entails the legal consequences described above.

Likewise, genocide is not an isolated category, separate from crimes against humanity, but a particular form of these crimes. All genocide involves the commission of crimes against humanity although the opposite is not always true. Therefore, all the legal consequences described above are also applicable to the crime of genocide.

Genocide includes any of the acts mentioned in Article 2 of the Convention on the Prevention and Punishment of the Crime of Genocide, when committed with intent to destroy in whole or in part a national, ethnical, racial or religious group as such. The difference between genocide and crimes against humanity is that genocide aims at the destruction of a group, and not just individuals within the group. Genocide discriminates against a group while crimes against humanity are directed indiscriminately against any civilian population.

The concept of genocide was foreshadowed in a qualitative distinction made by the Nuremberg Tribunal, through two definitions contained in its Statute:

- murder, extermination, enslavement, deportation and other inhumane acts committed against any civilian population, before or during the war, or

- persecutions on political, racial or religious grounds in execution of or in connection with, any of the crimes under the jurisdiction of the Tribunal, whether or not they constitute a violation of the domestic law of the country where they had perpetrated.

Thus, a distinction is made between two classes of victims:

- any civilian population: indiscriminate victims;

- specific groups persecuted intentionally: victims of discrimination. 
Ferreira

The main difference between crimes against humanity and genocide is the nature of the victims: the first case, the victims are chosen indiscriminately; in the second, they are well differentiated. The victims are indiscriminate when criminal action falls on anyone, regardless of their condition or circumstances - anyone, whoever they may be - and they are discriminated against when the criminal activity is directed not at an undifferentiated subject, but at a subject defined as belonging to a particular group.

The 1948 Genocide Convention characterized the crime of genocide as intent to destroy, in whole or in part, a national, ethnical, racial or religious group. This tight framework, with only four protected groups, has made the concept difficult to apply for several reasons, mainly because all genocides had political motives beyond the ways in which the perpetrators defined their victims. As Daniel Feierstein has pointed out, restricting the definition to four groups ignores two basic principles of law: equality before the law and the impossibility of creating a hierarchy of human life. A murder is always a murder, whoever is killed, but within the framework of the Genocide Convention, the deaths of some are more important than the deaths of others. ${ }^{4}$ Furthermore, the Convention expressly omits political groups, which were protected in the first and second draft of Article 2 of the Convention but were excluded from the final version due to geopolitical and not real philosophical or juridical reasons.

In a similar vein, Zaffaroni argues that the definition of genocide in the Genocide Convention is problematic because "it is clearly intended to impose two limitations: one objective, that is, the omission of political groups; and the other subjective, namely the intention to destroy the group totally or partially. These limitations cannot be explained rationally. There is no legal definition of murder anywhere in the world that ignores certain victims while at the same time requiring dolus directus of the first degree and excluding dolus indirectus or dolus eventualis. All over the world homicide is the killing of any human being." ${ }^{\text {As Resolution }}$ 96/1 of the UN which called for the Genocide Convention clearly pointed out: "Genocide is a denial of the right of existence of entire human groups, as homicide is the denial of the right to live of individual human beings" and, when referring to the groups, the Resolution included all possible groups under the sentence: "Many instances of such crimes of genocide have occurred when racial, religious, political, and other groups have been destroyed, entirely or in part". ${ }^{6}$

The tight framing or 'micro-surgical clipping' of the Convention has resulted in its apparent inapplicability to situations where an attack on people in one of the four protected categories has - supposedly - not been verified. Consequently, "in all subsequent massacres it has been possible to raise doubts about whether or not they were really genocides, with decisions being made purely in the short-term interests of the great powers". So, the existence of genocide in Cambodia was denied when Pol Pot exterminated 2,200,000 people between 1975 and 1979 (around one-fourth of the population), because the aim was not to eliminate the population but to politically cleanse the population of anyone infected with the 'bourgeois virus'. These 'class enemies' were anyone who had completed seventh grade and could read, or who did not belong to the class of poor peasants. ${ }^{8}$ Some have even argued there was no genocide in Rwanda, where Hutus eliminated a million Tutsis in 1994. Their argument is that not all deaths occurred as a result of a positive State action. ${ }^{9}$

\section{The difficulties of implementing the Convention on Genocide}

Argentina acceded to the Genocide Convention by Decree 6286/1956 of April 9, 1956, and incorporated it into the Constitution in 1994. Accordingly, the Convention takes precedence over domestic law. ${ }^{10}$ However, even those judges that refuse to endorse genocide charges have usually not disputed the historical fact that genocide took place. They simply question whether such charges are legally viable.

In sentencing ex-police chaplain Cristian Von Wernich, ${ }^{11}$ and former police commissioner Miguel Etchecolatz, ${ }^{12}$ Judge Carlos Rozanski was the first making limited use of the concept of genocide in the formula "crimes against humanity in the context of genocide", including as the charge of the sentence. In the "Suarez Mason"13 case, Judge Daniel Rafecas found it proven that the facts of the case "are undoubtedly a political genocide or politicide". In "Police Headquarters CDCs (Clandestine Detention Centers) / kidnappings and disappearances (2nd group)," Judge Daniel Bejas described the facts as "crimes that occurred within the context of the international crime of genocide". The Federal Court of Córdoba sentenced Menéndez ${ }^{14}$ for crimes against humanity, including genocide, and in Case 172/09, "Videla," it established that the events, that occurred in Penitentiary Unit No. 1 in Córdoba, were "genocidal practices constituting the crime of genocide." The Federal Court of Tucuman stated that the crimes against Vargas Aignasse ${ }^{15}$ deserved to be called genocide, but the term did not apply because the victim could not be included in any of the groups protected by the Genocide Convention. In the "Aguirre" case, the Tribunal found that the crimes were committed "in the 
context of the international crime of genocide". In the "Avellaneda" and "Campo de Mayo" cases, prosecutors Javier De Luca, Marcelo Garcia Berro and Patricio Murray argued that there had been a political genocide in Argentina. Alejandro Alagia, the prosecutor in the "Atlético-Banco-Olimpo" case, brought specific charges of genocide asking for a conviction for a genocide charge, even if the Tribunal finally convicted in that case for crimes against humanity.

In other words, the Argentine courts have so far not convicted anybody of genocide in Argentina until verdicts in 2012 and 2013 in the cases Madrid and Manacorda ${ }^{16}$ but in some previous cases they have recognized that genocide took place. Why? The arguments for not applying the term genocide until 2012 can be summarized as follows:

- Procedural arguments: a conviction for genocide would affect the principle of congruence because the defendants were not investigated for this crime until the cases Madrid and Manacorda, which started in 2011.

- Background legal arguments: (i) the Convention lacks regulation and applicable penalties; (ii) the cases do not fit into the categories of the Convention (mainly the question of the four protected groups).

\section{a) Procedural arguments}

Experts on criminal procedural law argue that the term genocide involves a violation of the principle of congruence because the defendants have not been investigated for this crime. However, there is a tendency to overlook the fact that the concept of genocide denotes not one crime but a whole category of offenses, and is a qualification added to certain crimes only when the element of genocidal intent has been proven.

Indeed, the defendants were not investigated for genocide or crimes against humanity, and could not have been, because those words do not designate specific crimes but sets of crimes, namely those resulting from the catalogs of Article 2 of the Convention on the Prevention and Punishment of the Crime of Genocide, and Article 6 and 7 of the Statute of the International Criminal Court. These crimes have their counterparts in the respective offenses of the Argentine Criminal Code, and it is the latter for which all defendants must be and, in fact, have been investigated.

As mentioned above, the concept of genocide is a qualification added to certain crimes. As such, it entails all the same material, personal, geographical and temporal consequences of crimes against humanity. However, it raises no procedural obstacles any more than does the category of crimes against humanity, which has been used many times by Argentine courts including the Supreme Court.

\section{b) Background legal arguments}

1. Lack of regulation and applicable sanction: it is objected that the crime of genocide is not punishable under the Argentine Criminal Code, so there is no assignment of penalties for the offense.

On the other hand, it should be noted that, as mentioned before, genocide as a crime under international law is a category of crimes that are defined individually and have their own specific penalties in the Argentine Criminal Code. The crime of genocide is not specifically provided for, but all individual crimes that can constitute genocide are included. Crimes against humanity are not provided for as a separate category in the Argentine Criminal Code, either. However, this does not prevent their qualification as crimes against humanity and there are a number of specific criminal offenses that can be classified in this way.

In addition, the issue of lack of sanction of genocide is not new but long-standing, and was finally settled some time ago at the level of international law. In fact, specific penalties and punishments for the practices complained of were absent in all the instruments of international criminal law until the adoption of the Rome Statute of the International Criminal Court in July 1998 (Article 77). Until then, all instruments, including the Charters of the Nuremberg and Tokyo Tribunals, lacked applicable penalties and punishments. Consequently, the penalties applied under the international rule of law were the same as those prescribed by national criminal law for similar offenses.

In this regard, the Statute of the International Criminal Tribunal for the Former Yugoslavia (ICTY) states that the penalties imposed by the Court shall be limited to imprisonment, and for the length of the sentence the Court shall be guided by general practice relating to sentences of imprisonment imposed by the courts of the former Yugoslavia (Article 24(1) of the Statute). And the same rule is laid down in Article 23(1) of the Statute of the International Tribunal for Rwanda (ICTR). 
An historical example is the trial of the former Gestapo chief in Lyon, Klaus Barbie, in France on July 4, 1987, for which he was sentenced to life imprisonment for seventeen crimes against humanity. In this case, the Nuremberg Charter was used to define the offense (because in France there was no offense called crimes against humanity), and the French Criminal Code was used for sentencing (to a period of imprisonment because France had already abolished the death penalty).

The Genocide Convention does not contain a description of the penalties to be applied in relation to each crime provided for, but transfers this responsibility to the competent authorities of the State party. Article 5 of the Genocide Convention provides that "The Contracting Parties undertake to enact, in accordance with their respective Constitutions, the necessary legislation to give effect to the provisions of the present Convention and, in particular, to provide effective penalties for persons guilty of genocide". The Convention gives each State the power to decide what those measures and penalties shall be.

Argentina acceded to the Genocide Convention by Decree 6286/56 of April 9, 1956, and the criminal penalties and punishments for conduct proscribed by it were already established in the Criminal Code before ratification just as the penalties and punishments applied to Klaus Barbie had already been established beforehand in France. Similarly, all of those convicted under the Nuremberg and Tokyo Statutes, or by the ad hoc Tribunals for the former Yugoslavia and Rwanda were sentenced according to national laws.

Indeed, as noted by Mirta Mántaras, the obligation under Article V of the Convention has been fulfilled with the rule which incorporated it into the Argentine legal system- Legislative Decree 6286/56 of April 9, 1956 - and no other specific law would be necessary, as the Convention details each of the actions that constitutes genocide: (a) killing members of the group; (b) causing serious bodily or mental harm; (c) deliberately inflicting conditions of life calculated to bring about physical destruction in whole or in part; (d) imposing measures intended to prevent births within the group; (e) forcibly transferring children of the group to another group. Mántaras argues that "if the offenses are accurately described, as they are here, the Convention is operational, which means that it applies directly to the judgment". ${ }^{17}$ Furthermore, criminal penalties and punishments are already incorporated into the Criminal Code, and are as follows: the killing of a group would be aggravated murder with life imprisonment (Articles 70-82 of the Criminal Code); serious physical or mental injuries are provided for in Articles 83-93 of the Criminal Code; unlawful detention is provided for in Articles 140-144 of the Criminal Code; and the forcible transfer of children from one group to another amounts to withholding or concealing minors and suppression of identity, included in Articles 149 and 138 of the Criminal Code. Furthermore, the Argentine Criminal Code allows multiple cases over the same subject matter - as in the case of genocide - to be assigned to the same judge. This makes large-scale convictions and punishments a real if little considered possibility. ${ }^{18}$

Moreover, the Argentine legal system expressly mentions genocide as an aggravating factor in Article 2 of Law 23.592, known as the anti-discrimination law: "The most lenient penalty on the scale of criminal penalties for offences punishable by the Criminal Code and supplementary laws shall be increased by one third and the harshest penalty by one half when the offence is committed by means of persecution or out of hatred of a race or religion or for the purpose of destroying all or part of a national, ethnic, racial or religious group. In no case may the punishment imposed exceed the applicable statutory maximum.”

Finally, in the present state of international law, a customary rule on genocide has gradually developed under which the Convention binds all States. There are no longer any escape routes: even States that have not ratified the Convention are bound by its terms. ${ }^{19}$ Thus, the International Court of Justice in its Advisory Opinion on Reservations to the Genocide Convention said that "the principles of the Convention are principles recognized as binding on the States by civilized nations, even in the absence of a treaty obligation". ${ }^{20}$

In short, any argument that asserts the inapplicability of the figure of genocide due to lack of regulation is unacceptable since no State can invoke the provisions of its internal law as justification for its failure to perform a treaty. ${ }^{21}$ To do so would put the Argentina in breach of its international obligations. ${ }^{22}$

2. Lack of fit with the categories of the Convention: The Genocide Convention provides four victim groups -national, ethnic, racial and religious, excluding political groups. So, it is argued that the Convention would be irrelevant to Argentina because the victims do not fit into any of these four categories. In Argentina a political struggle was waged between the military and armed left-wing groups, so that in any case it would be a political genocide, and as such excluded from the Convention definition.

This was the position of the amicus curiae brief filed by the human rights organization Nizkor in the case brought against Adolfo Scilingo in Spain, based on the analysis of Yale University's law clinic. Nizkor says: "The victims of the Argentine military were considered as targets for their alleged political beliefs ... they were 
not under attack 'by reason of their membership in a group' as required by the genocidal intent standard, but rather on the basis of their supposed individual political views."

A weaker version admits the existence of genocide but not the legal applicability of the Convention. In this regard, the Federal Court of Tucuman in the "Vargas Aignasse" case said: "This Court recognizes that the degree of blameworthiness in the crimes committed against Claudio Guillermo Vargas Aignasse is the same as that that required for the international crime of genocide as defined by the Genocide Convention and in this sense the crimes constitute genocidal practices and also their intellectual authors are clearly genocidaires under any non-legal definition of genocide, but, for the reasons mentioned ut supra, it is understood that the victim cannot be included in any of the protected groups of the Genocide Convention."

This article proposes that these interpretations are too narrow and do not match the real situation. It is right in principle to say that there was a political genocide, but the statement falls short: it was political, yet much more than political. The crimes committed during the self-styled "National Reorganization Process" constitute genocide under the terms of the 1948 Convention, and victims must fall into the category of partial national group, not merely political group, which is a much less comprehensive category.

The correct approach is that the 1976 dictatorship was not merely a response to the actions of the armed left, but a project to transform Argentine society as a whole. Terror was directed at each and every member of society in a systematic intent to transform the social relations of an entire people and bring about permanent changes in politics and the economy. Terror was thus directed at the entire population, and many of those killed were social, neighborhood and student activists - and even children without any political affiliation. In the words of Ibérico Saint Jean, a former de facto governor of Buenos Aires Province: "First we will kill all the subversives, then we will kill their collaborators, then their sympathizers, then those who remain indifferent, and finally we will kill the timid." ${ }^{23}$ On the other hand, if the process is seen as a confrontation between two groups, we fail to understand the perpetrators' intentional and systematic attempt at social and national reorganization. Not surprisingly the perpetrators defined extermination as a 'National Reorganization Process' and not one of political reorganization.

The military's own documents and regulations of the period defined the Argentine population as the objective. Annex 2 of the Army's Plan Contributing to the National Security Plan, in a section titled "Enemy status summary... A) Identifying the adversary defines the adversary or enemy as: “... all organizations or elements thereof in our country or that may arise in the process, which in any way oppose the takeover of power and / or hinder the normal development of the Military Government"24 Point B) then goes on to classify adversaries into 'Active' and 'Potential. The first turned out to be those who, at that time, opposed the takeover of power by parts of the armed forces and / or that might hinder the future development of the military government, while the latter were those who might do so in future. In other words, an adversary was anyone that might oppose them -in any way - in the present or future.

The military secret file RC-9-1, "Operations against subversive elements" is one of the best files to prove the dolus specialis required by the Genocide crime. Section 1017 stipulates: "In the operating environment, the status of the population is the most critical counter-subversion factor. It is here that the forces of law and order should focus their main attention."Section 2001 further adds that: "Any event, however insignificant, produces a dividend for political subversion ... it influences a subversive element which is of vital importance, namely, the population, by exploiting for conquest and domination what is commonly referred to as frustrations or dissatisfactions, whether national or sector-based."

"For these [frustrations or dissatisfactions] to exist, it is essential that they are recognized as such by the social group or sector that experiences them, that is, the following circumstances must exist:

- the group must consciously recognize a good as desirable;

- the same group or social sector must be aware, at the same time, that the desired good cannot be achieved under the current political, social or economic conditions."25

The same document in Annex 3 includes as active or potential adversaries "political-military, political and similar organizations, labor unions, student and religious organizations and persons connected with them". It further states that "the concept is prevention, not cure ... (Activists) should be captured immediately wherever they are, whether at home, on the street or at work (factory, office, educational institution, etc.)". In other words, workers, office workers, educators and students were all targets. Section 3021 also includes children: "The evacuation of detainees will occur as quickly as possible after separation by groups: leaders, 
men, women, children, immediately after capture." In the same line, Military Secret File C9-I/ 1977 establishes labor unionists and other social groups as the primary targets for 'preventive action'.

The "Psychological Operations Regulation"-Argentine Army RC-5-1-RESERVED is another fundamental file to prove the dolus specialis and it shows that State violence was not a reaction to the armed groups of the left, but was scheduled earlier. ${ }^{26}$ The document, signed by Alejandro Agustín Lanusse on November 8, 1968, states:

"1007. Classification of Psychological Operations: 1) National Strategic Psychological Operations: These will be directed at large segments of the country's population chosen as targets... "Section 2004, Compulsive action method: the compulsive action method will be any action that tends to motivate behaviors and attitudes by appealing to instincts. It will act on the instinct for self-preservation and other basic human tendencies (the unconscious). Psychological pressure will engender anxiety; massive, generalized anxiety may lead to terror and that is enough to keep the public (the target) at the mercy of any subsequent influence. [The use of] force will involve coercion and even mental violence. Usually this method will be driven, accompanied and supported by physical or material efforts tending towards the same result. Here, strength and vigor will replace the instruments of reason. The technique of physical deeds and hidden psychological methods will be channeled into producing compulsive action...

"10,008. Planning of psychological operations: 2) In preparing plans for psychological operations... it should be understood that among the above targets there are three main objectives: the [security] forces themselves, the civilian population and irregular enemy forces." ${ }^{27}$

The assertion that the entire population was a target for terror is also found in the words of the perpetrators themselves. "Little has been done to fulfill the other objectives that aim to defeat not only the guerrillas but subversion in toto". ${ }^{28}$ Another stated: "The aggressor in this type of struggle is not just the bomber, the gunman or the kidnapper. At the intellectual level, it is anyone that tries to change our way of life by promoting subversive ideas; in other words, who tries to subvert, change or disrupt [our] values [...] A terrorist is not just someone who kills with a gun or a bomb, but anyone who spreads ideas that are contrary to Western and Christian civilization".29 (Still another noted that: "It would be absurd to suppose that we have won the war against subversion simply because we have removed the armed threat [...] Residual elements of subversion are now appearing in religious, political, educational, economic, cultural and employment spheres.".

In recent declarations, Videla has stated quite bluntly that "Our goal was to discipline a society in the grips of anarchy, return it to its principles, its natural channels [...] A new model, a fairly radical change; society had to be disciplined for it to be more efficient." ${ }^{31}$

\section{Composition of the Generic Group}

It is contented here that, in the case of genocide, the victim group is not verified objectively, from a constant feature of reality, but is constructed subjectively through an intellectual operation. The group does not pre-exist 'as such' but is always constructed by the repressors who, according to one set of criteria or another, trace a circle around certain people, like a predatory animal stalking its prey. The genocidaires construct the group. Any group of people can fall victim to genocide.

The construction of the group as such is purely subjective: it is a slice of reality. Reality is cut into portions, one way or another, on the basis of an arbitrary decision. The group does not exist in nature, but only as an intellectual construction: a classification. This classification is cultural and subjective; there are no true or false classifications just as there are no true or false names. ${ }^{32}$

The International Criminal Tribunal for Rwanda said in relation to the classification of Hutus and Tutsis as "ethnic groups" that "for purposes of applying the Genocide Convention, the membership of a group is, in essence, a subjective rather than an objective concept. The genocide perpetrator perceives the victim as belonging to a group destined for destruction. In some cases, the victims may also perceive themselves as belonging to that group."33

In relation to Argentina, Mirta Mántaras has argued that in "Argentina the destruction of a national group took place. This group was not pre-existing, but was created by the perpetrators at the same time as individuals appeared expressing their opposition to the economic plan that had been implemented [...] The national group was gradually made up of workers, students, politicians, teenagers, children, employees, housewives, journalists and anyone who the perpetrators suspected for any reason of hindering the achievement of their goals (...) Most of these people did not know one another, but fell under the common denominator of 'opponent' (...) They did not need to carry out specific acts of opposition: the mere possibility 
that they might act in someone's defense was enough for the perpetrators to include them in the national group to be destroyed." 34

Similarly, Martin Losada has said that "the restrictive enumeration of protected groups should not make us lose sight of the fact that the choice of a group targeted for destruction is an essential element of genocide ... the victim-group is not always a social reality; it is often the result of a representation created by the murderers, who see it and construct it ideologically as a threat to their own survival." ${ }^{35}$

\section{Composition of the National Group}

The definition of the Argentine genocide as the elimination of the national group was first established by Judge Baltasar Garzón, who made it clear in his indictment of Scilingo and other Argentine military officials that 'the characterization as a 'national group' is absolutely valid for examining the events that took place in Argentina since the perpetrators intended to destroy a particular web of social relations in a State in order to bring about a change substantial enough to alter the life of the whole". ${ }^{36}$

However, Judge Garzón's interpretation was rejected on several doctrinal fronts, and his indictment was reversed in the Spanish National Court. The main challenge to the use of the term 'genocide' came from the amicus curiae brief filed by the human rights organization Nizkor. Based on an analysis by Yale University's law clinic, it argued that "National origin, as used in international instruments and literature, refers to persons having a certain culture, language and traditional way of life peculiar to a nation. ... Consequently, victims of the Argentine military were not a national group..." In the same way, the amicus curiae presented at the ABO trial by the European Centre for Constitutional and Human Rights, together with the legal expert opinion of Theo van Boven, excluded the term genocide on the grounds that the victims of massive human rights violations during the dictatorship were not a national group: "the victims of the Argentine military came from different cultures, different lifestyles and even different nations..."

Also, the judgments that sentenced Bussi (Head of the Third Army, in charge of the repression in the provinces of Córdoba and Tucumán) in the Vargas Aignasse case, and the murderers of Floreal Avellaneda, state that "The explicit meaning (of the expression 'national group')... is associated with the concern of the international community to provide protection to national minorities in the context of the emergence of multinational states at the end of the Second World War. Well, it is difficult to argue that Argentina was a multinational State at the time the events took place."

All these interpretations are, to some extent, contradictory. In Nizkor's analysis, victims do not constitute a national group because they are not united by a "certain culture, language and traditional way of life". This implies that each national group is a homogeneous group with a single language and culture, which is exactly the same interpretation that perpetrators, i.e. Nazis or Ittihadist perpetrators, use to think about their own societies. Van Boven says the same when he excludes from the national group cultures, ways of life and different nations, which, as such, would not be part of the national group because they are not alike. On the other hand, the Argentine courts have reached the opposite conclusion and suggest that the victims are not a national group because they are too much alike, and not multinational.

In either case, the victims cannot be a national group - because they are either too much alike, or too different. The hat is either too big or too small, and our head is to blame, not the size of the hat.

In addition, it seems that we are not even allowed to wear the hat, as it is a European garment far too elegant for us. To characterize the national group as a characteristic of multinational States is natural on a continent like Europe where many languages are spoken in the same country, and where, as a result of continuous wars, borders have, until recently, changed overnight, leaving national minorities trapped in hostile countries. With this criterion the Convention would apply only in Europe: a privilege of European nations. Legal rules should be interpreted according to the context in which they are applied, and must adapt to reality, not the reverse.

The common mistake or misconception is to define nationality in terms of supposedly objective criteria that do not stand up to scrutiny, and as such are unverifiable: language, culture and ways of life.

There are countries that have a unified language, culture and way of life, and constitute a nation. Some countries have multiple languages, cultures and ways of life and constitute a nation. Sometimes there is unity of language, culture and way of life in different countries (for example, Argentina and Uruguay). The prosecutor Alejandro Alagia argued in his submission in the ABO case that "When the French Declaration of Human Rights was passed in 1795, very few people spoke French. The most extreme case was the Italian nation, where only $2.5 \%$ of the population used the official language in everyday life. In conclusion, there is 
no reason to consider language or any other cultural criteria as an objective standard to identify the national group of the 1948 Convention."

Any supposedly objective investigation of nationality also implies discrimination because it does not even leave the victims with the status of nationals. This is no small mistake: Jews or Gypsies could not be Germans within the German nation. The attempt to define nationality in terms of objective criteria is then a tragic mistake, because it runs along the same line of reasoning that once allowed the Nazis to decide who formed part of the nation and who should be excluded. ${ }^{37}$

Finally, an objective nationality based on blood, race or language, ignores the Argentine National Constitution, which establishes residence for two consecutive years as the only requirement for foreigners wishing to obtain Argentine citizenship. Citizenship does not depend on any cultural criteria ${ }^{38}$ although "the authorities may shorten this term in favor of any applicant claiming and proving services to the Republic" (Article 20). Moreover, this formal and subjective criterion is unanimously accepted in international law, where the right not only to acquire but also to change one's nationality undermines any claim to objective criteria. $^{39}$

The national group is created by the bond between people as individuals and the nation: a purely formal and subjective criterion. The ICTR described it as follows: "it is comprised of individuals that share a legal bond based on common citizenship granting them reciprocal rights and obligations." ${ }^{30}$ Such is also the jurisprudence of the Inter-American Court of Human Rights in Advisory Opinion OC4/84, ${ }^{41}$ based on the doctrine established in 1955 by the International Court of Justice in The Hague in the Nottebohm case. ${ }^{42}$ The Court ruled that "Nationality is the political and legal bond that links a person to a given State and binds him to it with ties of loyalty and fidelity, entitling him to diplomatic protection from that State". ${ }^{43}$ This doctrine is mandatory for Argentina because Argentina's Supreme Court, in the "Giroldi" case, made the pronouncements of the Inter-American Court mandatory, including its judgments and advisory opinions. ${ }^{44}$

The concept of nationality thus defined does not indicate a person's ethnicity or sociological nationality but that person's political or legal nationality, ${ }^{45}$ which can only be conferred by the State. Indeed, the basic rule on this issue is that questions of nationality fall within the domestic jurisdiction of the State: only national law, not international law, can determine who are or are not nationals of a given country. ${ }^{46}$

\section{Composition of the partial national group}

The Convention on the Prevention and Punishment of the Crime of Genocide refers to crimes committed with the intent to destroy all or part of a group, which includes the partial national group. A partial national group is a part of the whole nation. But does this mean it is a subset or a cross-section of the population? In other words, when we speak of a national group, do we mean some or all members of the population? Is a national group essentially the same as an ethnic, racial or religious group or is it a broader-based notion?

Both the concept of genocide and the word itself were coined by Raphael Lemkin, who stated that "by genocide we mean the destruction of a nation or of an ethnic group". Lemkin argues that "Genocide is directed against the national group as an entity, and the actions involved are directed against individuals, not in their individual capacity, but as members of the national group". In short, genocide is the destruction of a national or ethnic group. Yet in a footnote Lemkin clarifies the concept of ethnicity: "another term could be used for the same idea namely, 'ethnocide' consisting of the Greek word 'ethnos' and Latin 'cide."' ${ }^{37}$ For Lemkin, the concept of ethnicity overlaps to a certain extent with that of national group. Lemkin continues by saying that "Genocide has two phases: one, destruction of the national pattern of the oppressed group, the other, the imposition of the national pattern of the oppressor". The concept of national pattern clearly prevails. Lemkin does not say ethnic, racial or religious but national pattern. ${ }^{48}$

He also clearly states that the national group is the generic term. He says: Many authors, instead of using a generic term used current terms connoting only some functional aspect of the main generic notion of genocide. Thus, the terms 'Germanization,' 'Magyarization,' 'Italianisation', for example, are used to connote the imposition by a stronger nation (Germany, Hungary, Italy), of its national pattern upon a national group controlled by it." 49

It is clear that, in contrast to the generic term, the specific terms also refer to national groups. That is "the main generic notion of genocide". So strong is this idea that Lemkin says that "nations are essential elements of the world community. The world represents only so much culture and intellectual vigor as are created by its component national groups... the destruction of a nation, therefore, represents the loss of its future contributions to the world." 50 
The notion of nation also predominates when Lemkin describes 'Techniques of genocide in different fields' in Chapter IX of his book. The fields in question are: political, social, cultural, economic, biological, physical, religious and moral. In the political field, he says, "The techniques of genocide, which the German occupant has developed in the various occupied countries, represent a concentrated and coordinated attack upon all elements of nationhood: ...In order further to disrupt national unity, Nazi party organizations were established... In line with this policy of imposing the German national pattern.".51

Regarding the social field, Lemkin says that "The destruction of the national pattern in the social field has been accomplished in part by the abolition of local law and local courts and the imposition of German law and courts, and also by Germanization of the judicial language and of the bar. The social structure of a nation being vital to its national development, the occupant also endeavors to bring about such changes as may weaken the national spiritual resources." ${ }^{52}$ Regarding the cultural field, Lemkin argues that "In order to prevent the expression of the national spirit through artistic media, a rigid control of all cultural activities has been introduced. All persons engaged in painting, drawing, sculpture, music, literature, and the theater are required to obtain a license for the continuation of their activities." ${ }^{53}$

Concerning the economic field, he says that "Participation in economic life is thus made dependent upon one's being German or being devoted to the cause of Germanism. Consequently, promoting a national ideology other than German is made difficult and dangerous." ${ }^{34}$ About the biological field, Lemkin says "In the occupied countries of "people of non-related blood," a policy of depopulation is pursued... [through] the adoption of measures calculated to decrease the birthrate." ${ }^{55}$ Concerning the physical realm, he says "The physical debilitation and even annihilation of national groups in occupied countries is carried out mainly in the following ways: I. Racial Discrimination in Feeding... 2. Endangering of Health... and 3. Mass Murder" ${ }^{36}$ In the religious field, he states that "[i]n Luxemburg, where the population is predominantly Catholic and religion plays an important role in national life, especially in the field of education, the occupant has tried to disrupt these national and religious influences."57 About the moral field, Lemkin believes that "[i]n order to weaken the spiritual resistance of the national group, the occupant attempts to create an atmosphere of moral debasement within this group... According to this plan, the mental energy of the group should be concentrated upon base instincts and should be diverted from moral and national thinking.",58

It is clear then that for Lemkin the national group was broader in scope than an ethnic, racial or religious group. The national group in principle includes all members of the nation and the remaining groups, by definition, are subsumed into this larger group. The inclusion of ethnic, racial and religious groups is meant to highlight typical cases of genocide, but these groups do not exhaust the meaning of the word genocide. Moreover, the national group subsumes and surpasses the others: it refers to ethnic, racial and religious groups and something more. Indeed, it covers any group not included in the ethnic, racial or religious categories. Thus it contains all minority groups that may be subject to persecution, whoever they may be. This includes groups that share a different membership criteria from ethnicity, race or religion, such as: the elderly, transvestites, the disabled, the ugly, or whoever. The national group thus has an inner limit, covering ethnic, racial and religious groups, and an outer limit, which goes beyond the previous one and includes other possible groups.

Any other interpretation inevitably leads to discriminatory consequences, both in terms of what the national group covers (its inner boundary) as what the national group exceeds (its outer boundary). Thus:

- Inner boundary: if we hold that the national group does not cover ethnic, racial or religious groups, we commit the same discrimination as the Nazi genocidaires, who excluded Jews and other groups from the German nation. In their view, Jews, homosexuals, the disabled, etc., were not Germans but something different, only fit to be exterminated. The same applies to all cases of genocide, including Argentina's.

- Outer boundary: if the national group does not include sexual minorities, the elderly, the disabled, etc., then the principle of equality before the law is violated. To interpret the Convention as meaning that some lives are more important than others is to create an unacceptable hierarchy of human existence.

Such is the extent of the partial national group, and any other interpretation that excludes groups or individuals smacks of violation of the principle of equality before the law enshrined in Article 16 of the Argentine Constitution. This should be understood at a universal level and at all national legal levels because Advisory Opinion 18/2003 of the Inter-American Court of Human Rights on "Status and Rights 
of Undocumented Migrants" established that the fundamental principle of equality and non-discrimination belongs to the domain of jus cogens, and consequently "entails obligations erga omnes on third parties". Also, that Advisory Opinion reminds us that under the International Covenant on Civil and Political Rights, the Human Rights Committee noted the broad scope of Article 26 of the Covenant, which establishes the basic principle of equality and non-discrimination, and its General Comment No. 18 held on this principle that Art. 26 of the Covenant provides in itself an "autonomous right", and the application of that principle in the content is not limited to the rights set forth in the Covenant. This enlightened approach of the Human Rights Committee contributed to the ruling by the European Court of Human Rights on a violation of Art.14 of the European Convention on Human Rights in the Case Gaygusuz versus Austria (1996), as well as the requirements established in legal doctrine that "distinctions" must be reasonable and consistent with the law (to avoid discrimination) have led to the suggestion that a true "right to equality" has emerged.

\section{Conclusion: The construction of memory and the value of truth}

Even though most jurists consider sentencing to be important, legal characterizations are much more so. Much more important than the punishment of criminals is the construction of collective memory. It is important to uncover the truth about massive human rights abuses because concealing the truth causes great harm. ${ }^{59}$ I suggest that the terms genocide and crimes against humanity have different connotations. Genocide implies a collective responsibility. As genocide aims at the elimination of the group, it involves us all: we cannot say others were guilty or unfortunate. Crimes against humanity are construed differently: multiple individual isolated crimes can be watered down and alienated as someone else's problem.

The choice between treating human rights abuses in Argentina as the genocide of a national group or merely as thousands of unconnected crimes against humanity (even if part of a widespread or systematic attack) involves two different ways of constructing the past, each linked to a different social model. A caring society, which is precisely what the dictatorship set out to repress, or a law-of-the-jungle society, which is precisely what they tried to establish and which flourished in the 1990s - a society that promoted shameless self-interest, an "I'm alright, Jack" attitude, unbridled frivolity, and the forced imposition of an economic model that Argentine society had rejected for decades. Thousands of convictions for unconnected offenses not only hides the truth but also perpetuates the greater crime of the destruction and transformation ('reorganization', in the words of the perpetrators) of the whole national group. It is necessary, then, to salvage the truth and recognize that genocide - rather than crimes against humanity - took place in Argentina; and that it was genocide against a national rather than a political group.

Legally speaking, the figure of Genocide is directly applicable in Argentina's domestic legal order as a customary international law norm ratified by the State in 1956 through the ratification of the United Nations Genocide Convention. In this interpretation, the national group is not defined by supposedly objective criteria, such as the unity or plurality of language, culture and ways of life (sociological nationality), but by the purely formal and subjective criteria of the legal bond between people and the nation (legal nationality), a criterion imposed by Argentina's various domestic legal systems, as well as by international law in general.

In Lemkin's work, the national group is the generic group, which both includes and goes beyond ethnic, racial and religious groups, and also allows the incorporation of any other group that could be a victim of the crimes defined in the Convention. This conclusion is also universal, based on the basic principle of equality and non-discrimination.

\section{End Notes}

1. In this regard, the Court of Cassation, Argentina's highest criminal court, issued on February 28, 2012, Policy Decision 1/2012-CFCP (Complex cases - rules and practices) - which established a series of rules for the purpose of simplifying the work of the courts, such as use of video and audiovisual media used in other trials or elsewhere, the reading of testimonies included in other trials, use of telecommunications technologies, such as videoconferencing, in cases where witnesses or the accused cannot appear due to health reasons, or whenever necessary to ensure the protection of the safety and dignity of the victims or witnesses, or they reside in a long way from the courthouse or abroad, or to avoid delays in the hearings.

2. See PARENTI, Paul F., FILIPPINI, Leonardo G., FOLGUEIRO, Hernan L. "Los Crímenes contra la humanidad y el genocidio en el derecho internacional" ("Crimes against humanity and genocide in international law,") Ad-Hoc, Buenos Aires, 2007, p. 11/67.

3. See FERREIRA, Marcelo, "Crímenes de lesa humanidad: fundamentos y ámbitos de validez" ("Crimes against humanity: Foundations and fields of validity") in Agustín Gordillo, "Derechos Humanos" ("Human Rights,") Fundación de Derecho Administrativo, Buenos Aires, 2005, Chapter XV, p. 1/53 
4. FEIERSTEIN, Daniel, "El genocidio como práctica social, entre el nazismo y la experiencia argentina" (“Genocide as Social Practice. Reorganizing Society under the Nazis and the Argentina's Military Juntas") Fondo de Cultura Economica, Buenos Aires, 2007, p. 42 onwards. An English version in press in Rutgers University Press, forthcoming 2014.

5. ZAFFARONI, Raul E., "La palabra de los muertos. Conferencias de Criminología Cautelar" ("The word of the dead. Conferences on Cautious Criminology"), Ediar, Buenos Aires 2011, p. 424.

6. United Nations General Assembly Resolutions, Resolution 96/1, December 11th, 1946.

7. ZAFFARONI, op. cit., p. 425.

8. POWER, Samantha, A Problem from Hell: America and the Age of Genocide Power. New York: HarperCollins, 2002 Chapter VI.

9. ZAFFARONI, op. cit., p. 426.

10. Article 75 para. 22 of the Argentina National Constitution establishes the authority of Congress: "To approve or reject treaties concluded with other nations and international organizations, and concordats with the Holy See. Treaties and agreements take precedence over the laws. The American Declaration of the Rights and Duties of Man, the Universal Declaration of Human Rights, the American Convention on Human Rights, the International Covenant on Economic, Social and Cultural Rights, the International Covenant on Civil and Political Rights and its Optional Protocol, the Convention on the Prevention and Punishment of the Crime of Genocide, the International Convention on the Elimination of all Forms of Racial Discrimination, the Convention on the Elimination of All Forms of Discrimination against Women, the Convention against Torture and Other Cruel, Degrading Treatment or Punishment, the Convention on the Rights of the Child, to the extent that they are applicable, have constitutional status, do no repeal any section of the first part of this Constitution and should be understood as complementing the rights and guarantees recognized therein . They may be denounced, where necessary, only by the national Executive, following approval of two-thirds of all the members of each House." In interpreting this rule, Adelina Loianno argues that "it is clear that the constituent has sought to place the eleven international instruments referred to in the para. 22 Article 75, on the same level as the Constitution. References to the complementarity of existing constitutional provisions, which are not repealed, entrench the meaning of hierarchy already referred to" (Loianno, Adelina, Esquema actual de la supremacía consitucional (Current system of consitucional supremacy), in Gordillo, Agustín, Derechos Humanos, Fundación de Derecho Administrativo (Human Rights, Foundation of Administrative Law), 5th edition, Buenos Aires, 2005, p.iii -17. In this respect, Agustín Gordillo says that "in human rights in general we have to comply with a supranational and supraconstitutional legal order, which is directly and immediately applicable in domestic law by judges and other national organs of the State" (Gordillo,Agustín, op . Cit..id, p.iii -2) .

11. Christian Von Wernich is an Argentine priest of the Catholic Church who served as a police chaplain in the Province of Buenos Aires during the dictatorship. He was convicted for complicity in illegal deprivation of liberty and torture in numerous clandestine detention centers. He is currently detained in the prison of Marcos Paz.

12. Miguel Etchecolatz is a former police officer who served as Director of Police Investigations in the Province of Buenos Aires between March 1976 and late 1977. He was General Ramón Camps' right -hand man. He was sentenced to life imprisonment for numerous counts of unlawful deprivation of liberty, torture and murder. The witness Julio Jorge Lopez, who testified against Etchecolatz in the trial cited above, is currently missing believed dead.

13. Former General Carlos Guillermo Suarez Mason was head of the First Army Corps between 1976 and 1979. The secret detention centers of Automotores Orletti, Pozo de Banfield, La Cacha, and El Olimpo all operated in his jurisdiction. He also joined the Masonic lodge Propaganda Due, led by Licio Gelli. He was pardoned by former President Carlos Menem, but died in prison while being investigated for the theft of babies born in captivity and other crimes committed in secret detention centers. He was sentenced in absentia to life imprisonment by the Italian justice for the kidnapping and murder of Italian citizens living in Argentina during the dictatorship.

14. Luciano Benjamin Menendez was Major General in charge of the Third Army Corps during the dictatorship. During the preparations for war with Chile in 1978 over the disputed Beagle Channel, he said "if they let us attack the chilotes attack, we'll push them back to Easter Island, we'll have our New Year's Eve toast in the Palacio de la Moneda, and afterwards we'll go piss the champagne into the Pacific." Menendez was sentenced to life imprisonment on numerous occasions for crimes against humanity.

15. Guillermo Vargas Aignasse was Senator for the province of Tucumán. He was kidnapped on March 24, 1976. His body was found in a mass grave in the clandestine detention center known as Pozo de Vargas on December 15, 2011.

16. Cases Madrid (3224/2011) and Manacorda (Case 3329/2011) were about the abduction and appropriation of children whose mothers were kidnapped and disappeared. The perpetrators were convicted of the charge of complicity in the Argentine genocide. These were the first convictions for genocide produced in the Argentine justice system.

17. MÁNTARAS, Mirta, “Genocide in Argentina”, Buenos Aires, Chilavert, 2005, p. 70.

18. MÁNTARAS, Mirta, op. cit., p. 70/71.

19. LOZADA, Martin, "El crimen de genocidio: su reno-vada dimensión a 60 años de su construcción conceptual” (“The crime of genocide: its renewed dimension 60 years after its conceptualization"), Inter-American and European Human Rights Journal, Volume 2, No. 1-2-2009, p. 177.

20. ICJ (Advisory Opinion) 28 May 1951, "Reservations to the Convention on the Prevention and Punishment of the Crime of Genocide”, ICJ Reports (1951), p. 15, para. 24.

21. Article 27 of the Convention on the Law of Treaties 
22. In this sense, the obligation of States to investigate, prosecute and punish those responsible for crimes against humanity today is a peremptory norm of international law belonging to the category of jus cogens, independently of the criteria that may be established in these States' domestic law. This criterion was applied by the Court in Case 17,439 in re "Pinochet Ugarte, Augusto / no statute of limitations for criminal proceedings", resolution of May 15, 2001, record 18,657, emphasizing the principle that the State cannot invoke internal difficulties to neglect its duty to investigate the facts and punish those criminally responsible.

23. Statements by Saint Jean to the International Herald Tribune, May 26, 1977.

24. MÁNTARAS, Mirta, op. cit., p. 143.

25. MÁNTARAS, Mirta, op. cit., p. 201.

26. It is remarkable that these psychological developments have proliferated in a medium that is so hostile to this kind of thinking. In this regard, René Kaës recounts that "therapy groups were particularly subject to police repression during the dictatorship years: persecuted, banned or dissolved, they were suspected to be considered places of social subversion". And the military's discourse itself stated that "if we allowed the proliferation of corrosive elements-psychoanalysts, psychiatrists, Freudians, etc. - stirring up people's consciences and questioning national and family roots, we would be defeated" (General Acdel Vilas). This apparent contradiction reveals how deep the roots of the sinister repressive plot went: far from being a primitive and violent gut reaction, it was instead the result of a premeditated and rational process, cold and terrifyingly calculated (KAËS, René, "Rupturas catastróficas y trabajo de la memoria. Notas para una investigación", ("Catastrophic ruptures and memory work. Research notes") in PUGET, Janine and KAËS, René [eds.], "Violencia de Estado y Psicoanálisis", ("State Violence and Psychoanalysis”), Group Editorial Lumen, Buenos Aires, 2006, p. 172.

27. pp. 6, 16, 157.

28. 'National Project' developed in 1976 by the military dictatorship’s Ministry of Planning, under General Diaz Bessone.

29. Jorge Rafael Videla, in La Prensa, December 18, 1977.

30. Carlos Suarez Mason, in La Prensa, July 7, 1979.

31. REATO, Ceferino, "Disposición Final. La confesión de Videla sobre los desaparecidos" ("Final Disposition. Videla’s confession about the missing"), Sudamericana, Buenos Aires, 2012, p. 159.

32. GUIBOURG, Ricardo A., GHIGLIANI, Alexander M., GUARINONI, Ricardo V., "Introducción al conocimiento científico" ("Introduction to scientific knowledge"), Buenos Aires, Eudeba, 1994, p. 37 onwards.

33. The Prosecutor v. Rutaganda (Case ICTR-96-3), Judgment and Sentence, December 6, 1999, paragraphs 56-58, p. 373.

34. MÁNTARAS, Mirta, “Genocidio en Argentina” (“Genocide in Argentina,”) op. cit., p. 68.

35. LOZADA, Martin, "El crimen de genocidio. Un análisis en ocasión de su 50 aniversario" ("The crime of genocide. An analysis on the occasion of its 50th anniversary,") published in Cuadernos de Doctrina y Jurisprudencia, Volume 5 No. 9-A1999, Ad-Hoc, Buenos Aires, p. 807

36. Fragment of the indictment issued by Judge Baltasar Garzón, November 2nd, 1999. Madrid.

37. See the consequences of the different analysis of Nazism and the role of the understanding of the groups in Daniel Feierstein; "The Concept of Genocide and the Partial Destruction of the National Group", Logos. A Journal of Modern Society and Culture, Vol. 11, Issue 1, 2012, ISSN 1543-0820, URL: http://logosjournal.com/2012/winter_feierstein

38. Translator's note: This is not strictly speaking true. Article 25 of the Argentine Constitution begins by saying: "The Federal Government shall foster European immigration", however this does not contradict the main argument of the author.

39. American Declaration of the Rights and Duties of Man, Art. XIX: "Every person has the right to the nationality to which he is entitled by law and to change it, if he so wishes, for the nationality of any other country that is willing to grant it to him"; Universal Declaration of Human Rights, Art. Article 15. (1) Everyone has the right to a nationality. (2) No one shall be arbitrarily deprived of his nationality nor denied the right to change his nationality. The American Convention on Human Rights, Article 20. Right to Nationality (1) Every person has the right to a nationality. (2) Every person has the right to the nationality of the state in whose territory he was born if he does not have the right to any other nationality. (3) No one shall be arbitrarily deprived of his nationality or of the right to change it. International Covenant on Civil and Political Rights, Art. 24.3: "Every child has the right to acquire a nationality."

40. The Prosecutor v. Jean Paul Akayesu, Trial Judgment, 2 September 1998, ICTR-96-4-T para. 511-515.

41. Commission, OC-4/84 of January 19, 1984, Series A No. 4, No. 22.

42. ICJ Reports 1955, p. 23.

43. At para. 35.

44. GIROLDI, Horacio D. and another, LA LEY, 1995-D, 463. In this regard, see: LOIANNO, Adelina, "Incidencia de la Jurisprudencia de la Corte Interamericana y de las recomendaciones de la Comisión en el derecho interno" ("Impact of the Jurisprudence of the Court and of the recommendations of the Commission on national law") in GORDILLO, Augustine, "Derechos Humanos", 5th ed., Fundación de Derecho Administrativo, Buenos Aires, 2005, p. III-17 onwards.

45. In this regard, Bidart Campos distinguishes between nationality, sociological nationality, and political citizenship. He says the first is acquired spontaneously, and is not susceptible to regulation by the positive law of the State. While political nationality is what a person has under statutory law, and is defined as the legal position is invested with by the positive law of the State in relation to the same "State", according to a criterion that adopts law (e.g., place of birth, nationality or father, or citizenship, or residence, etc.) (CAMPOS Germán Bidart, "Elementary Treatise on Constitutional Law Argentino", Vol. I, Ediar, Buenos Aires, 1985, p. 124). 
46. OYARZABAL, Mario JA, "La nacionalidad argentina. Un estudio desde la perspectiva del derecho internacional público, del derecho internacional privado y del derecho interno argentino, con referencias al derecho de la integración" ("Argentine Nationality. A study from the perspective of public international law, private international law and Argentine law, with references to the right of integration"), La Ley, Buenos Aires, 2003, p. 8. The principle of the exclusive competence of the State was confirmed by the Permanent Court of International Justice in its advisory opinion concerning Nationality Decrees in Tunisia and Morocco: "The question whether a certain matter is or is not solely within the jurisdiction of a State is an essentially relative question: depends on the development of international relations. Thus, in the present state of international law, questions of nationality are, in the opinion of this Court, in principle within this reserved domain." The Hague Convention on Certain Questions Relating to the Conflict of Nationality Laws of 1930 established that "It is for each State to determine under its own law who are its nationals..." (Art. 1), and that "Any question as to whether a person possesses the nationality of a particular State shall be determined in accordance with the law of the State."(Art. 2). In the aforementioned Nottebohm case, the International Court of Justice determined that "international law leaves it to each State to lay down the rules governing the grant of its own nationality."

47. LEMKIN, Raphael, Axis Rule in Occupied Europe, The Law Book Exchange Ltd. Clark, New Jersey, [1944] 2005. p. 79.

48. LEMKIN, Raphael, op. cit., id.

49. LEMKIN, Raphael, op. cit., p. 80.

50. LEMKIN, Raphael, op. cit., p. 90.

51. LEMKIN, Raphael, op. cit., p. 82-83.

52. LEMKIN, Raphael, op. cit., p. 83.

53. LEMKIN, Raphael, op. cit., p. 84.

54. LEMKIN, Raphael, op. cit., p. 86.

55. LEMKIN, Raphael, op. cit., p. 86.

56. LEMKIN, Raphael, op. cit., p. 87-88.

57. LEMKIN, Raphael, op. cit., p. 89.

58. LEMKIN, Raphael, op. cit., p. 89-90.

59. In this regard: TISSERON S., TOROK M., RAND C., NACHIN C., HACHET P., ROUCHY J. C., "El psiquismo ante la prueba de las generaciones. Clínica del Fantasma" ("The psyche before the generation test. A Clinical Study of Ghosts"), Amorrortu, Buenos Aires, 1997. Also: SHÜTZENBERGER, Anne Ancelin, “iAy, mis ancestros!” (“Oh, my ancestors!”) Omeba, Buenos Aires, 2006. Also, the French psychiatrist Françoise Dolto says that "what is silenced in the first generation is buried in the body in the second generation" and the trauma transmitted is much greater than the trauma received: the children of Holocaust survivors are three times as likely to suffer from post-traumatic syndrome as their parents. Dolto claims that silent parents convey an unspoken message that is processed by their children and turned into the unspeakable, but also by the grandchildren, who turn it into the unthinkable. Thus, in the third generation, the unspeakable becomes the unthinkable, which then becomes a ghost that haunts all of them. The trauma and pain are transmitted through the centuries. Mehmet Ali Agca wrote, the day before he shot the Pope on May 13, 1981: "I have decided to kill John Paul II, Supreme Commander of the Crusades": a thousand years later the wound is still open, and Muslims still talk about genocide. In the same vein, Freud says that "Without the assumption of a mass psyche, or a continuity in the emotional life of mankind which permits us to disregard the interruptions of psychic acts through the transgression of individuals, social psychology could not exist at all. If psychic processes of one generation did not continue in the next, if each had to acquire its attitude towards life afresh, there would be no progress in this field and almost no development." (FREUD, Sigmund, Totem and Taboo, Cosimo Classics: New York, p. 203). 